\title{
Isolation and identification of potent tributyltin chloride utilizing Pseudomonas sp. strain VBAK from Vishakhapatnam shipping harbor sediments
}

\author{
Battu Anand Kumar ${ }^{1}$, Triveni Gummadi ${ }^{1}$, Bhargava Ram Gundluri ${ }^{1}$, Chanda Vikrant Berde ${ }^{2}$, Veera Bramhachari Pallaval ${ }^{1 *}$ \\ ${ }^{1}$ Department of Biotechnology, Krishna University, Machilipatnam, India. \\ ${ }^{2}$ School of Earth, Ocean and Atmospheric Sciences, Goa University, Taleigao, India.
}

\section{ARTICLE INFO \\ Article history: \\ Received on: July 06, 2021 \\ Accepted on: October 30, 2021 \\ Available online: February 15, 2022}

Key words:

Dibutyltin, mineral salt medium,

Pseudomonas sp., thin-layer

chromatography, tributyltin

\begin{abstract}
Screening for tributyltin (TBT)-resistant and degrading bacteria was pertinent for the selection of isolates with decontamination ability of TBT. With this rationale, 205 strains were isolated from Vishakhapatnam shipping harbor sediments and their tolerance limit to TBT was evaluated in minimal salts media containing $2 \mathrm{mM}$ TBT as the sole carbon source. Fourteen selective TBT-resistant isolates showed cross-tolerance to heavy metals and antibiotics. Among them, one interesting isolate VBAK, showing the highest TBT resistance and maximum growth yield, was selected and taxonomic identification was carried out by sequencing 16S rRNA gene. The maximum composite likelihood algorithm formed a coherent cluster with clad comprised Pseudomonas sp. The thin-layer chromatography profile of the degradation product revealed the depletion of TBT into dibutyltin. The $R f$ values of TBT and transformed compounds were 0.8 (solvent front $=16.5 \pm 2$, TBT $9.1 \pm 1.0$ ) and 0.7 (solvent front $=6.5 \pm 2$, product $6.8 \pm 2$ ), respectively. These results suggest that Pseudomonas sp. strain VBAK is potentially useful for bioremediation of TBT contamination.
\end{abstract}

\section{INTRODUCTION}

The toxicity of tributyltin (TBT) compounds has become a unique focusing point for research because of its extensive usage as biocides (fungicide, bactericide, and insecticide) in marine paints and coatings as antifouling applications, preservatives for wood, textiles, paper, and leather industries [1]. The use of TBT as antifouling agents in marine paint formulations has been significantly increased in the shore waters mainly due to its longer resilience, high efficiency, and reasonable cost. This biocide also prevents the attachment of barnacles and slime on boat hulls, aquaculture nets, commercial boats, and naval ships [2]. TBT toxicity is widely known to cause detrimental effects on various marine living organisms, viz. endocrine disruption, impairment in cell growth, cell malformation and imposex, development and reproduction, influence on the shell fishery, and harm algal photosynthesis, which could also promote adverse effects in

*Corresponding Author

Pallaval Veerabramhachari, Department of Biotechnology, Krishna University, Machilipatnam, India.E-mail: veerabramha@gmail.com diverse organisms from snails to mammals [3]. Once released from antifouling paints, TBT is rapidly absorbed by organic material such as bacteria and algae or suspended particles in the water columns [4].

The International Maritime Organization has completely prohibited the usage of these compounds in marine antifouling paint formulations [4-6]. Despite the regulations enforced to limit their use as antifoulants, TBT is still present at toxic levels in the water columns and sediments of Vishakhapatnam harbor [7]. The port of Visakhapatnam is one of the major ports of India having a record of handling the largest volume of cargo including POL, iron ore, finished fertilizers, and thermal and cooking coal. Recently, Garg et al. [8] reported that concentrations of TBT in the sediments were as high as 6,381 and 10,968 $\mathrm{ng} \mathrm{Sn} \mathrm{g}^{-1}$, which could be toxic to a diversified range of aquatic organisms. So TBT pollution in this harbor is of great concern. It was interesting to note that only TBT is used as an antifouling paint in this harbor. In compliance with this, we tested the hypothesis after witnessing the recent research report of dibutyltin (DBT) levels $\left(4,459 \pm 697 \mathrm{ng} \mathrm{Sn} \mathrm{g}^{-1}\right)$ in the harbor sediments [7]. 
Based on the published literature, we presumed the active role of microbial transformation of TBT to DBT in harbor sediments. Under favorable conditions, TBT degrades through successive dealkylation to produce DBT, monobutyltin, and ultimately inorganic tin, via UV radiation, warmer temperatures, and microbial activity, with microbial activity being of greater importance. Because of this, it is also interesting to note that microorganisms are predominating in harbor sediments colonizing on antifouling paint scraps that contain high levels of TBT $[9,10]$. Interestingly, sediment bacterial communities are particularly useful and sensitive biomonitoring tools while studying sediments contaminated with toxic pollutants [11]. The isolation and characterization of TBT-resistant marine bacterium, Alteromonas sp. M-1, was the first record of its kind [12].

Several reports have evidenced the studies on the isolation and characterization of TBT resistant bacteria from Indian coastal shore waters [13-15]; however, only a few reports revealed the detoxification of TBT mediated by microorganisms $[1,12,14]$. On the contrary, the reports are also meager on TBT-utilizing bacteria. Interestingly, microbial degradation was observed to be the predominant process for the breakdown of TBT biocide in Indian shore waters, with DBT as the major transformation product [14]. Recent pieces of evidence on extensive TBT contamination in the west coast and east coast shore waters of India raised a serious concern for the existence of TBT-tolerant bacteria in Vishakhapatnam harbor. Moreover, TBT was found to be most abundant among the organotin compounds in Vishakhapatnam harbor sediments, off the east coast of India, indicating fresh inputs of TBT during 2011-2012 owing to massive ship traffic in the shipyard [8]. However, studies related to the occurrence of TBTutilizing bacteria inhabiting the east coast harbors are not available. Hence, we report here studies on a natural bacterial isolate, obtained from marine sediment waters from Vishakhapatnam harbor, capable of utilizing TBT as the sole source of carbon, with the ability to degrade TBT into less toxic compounds, and molecular identification of the strain. One particular isolate, Pseudomonas sp. strain VBAK, fulfilled all the characteristics needed for its future application as a potent bioremediation tool for TBTcontaminated areas. Therefore, it was interesting to investigate the microbes capable of transforming TBT into less toxic compounds. Since resistance to heavy metals and antibiotics is common among TBT-resistant organisms, studying TBT resistance might be vital for the restoration of TBT-contaminated environments. Therefore, it was imperative to identify the isolated bacteria in this study and extend the knowledge on TBT-resistant bacteria.

\section{MATERIALS AND METHODS}

\subsection{Physicochemical Parameters}

Vishakhapatnam port is situated between latitude $15^{\circ} 27^{\prime} 010^{\prime \prime} \mathrm{N}$ and longitude $73^{\circ} 49^{\prime} 996^{\prime \prime} \mathrm{E}$. Due to extensive ship-related activities, this site was selected for study. All sediment samples were collected at 10-20 m depth using a grab sampler and were stored in polycarbonate glass bottles under $4^{\circ} \mathrm{C}$ and shipped to the laboratory until further analysis. TBTCl was purchased from Merck (India); the stock solutions were prepared in ethanol and then stored at $4^{\circ} \mathrm{C}$. Physicochemical parameters of surface and sediment waters, viz. temperature $\left({ }^{\circ} \mathrm{C}\right), \mathrm{pH}$, salinity, alkalinity, chlorinity, dissolved oxygen, and inorganic contents (phosphates nitrates and nitrites), were measured following the standard procedures of Grasshoff [16]. Organic carbon was measured using CNS elemental analyzer (Thermo, Flash EA, 1112 series) following the method described by Harji et al. [17].

\subsection{Determination of Viable Counts}

The total viable counts of the surface waters and sediment samples were enumerated on Zobell marine broth (ZMB) agar (HiMedia) and mineral salt media (MSM) agar containing 0-2 mM TBT as described previously $[13,18]$. TBT-resistant bacteria were defined as those growing on agar plates containing $2 \mathrm{mM}$ TBT.

\subsection{Physiological and Biochemical Characteristics}

$\beta$-lactamase activity was assayed by the acidometric method [19]. Briefly, $125 \mu \mathrm{l}$ of aqueous solution containing $0.2 \%$ soluble starch $(w / v)$ and $1 \%$ benzylpenicillin $(w / v)$ was added to the wells of 96well microtiter plates. $50 \mu \mathrm{l}$ of 12-hour-grown bacterial cultures were mixed with the abovementioned solution and incubated for $30^{\circ} \mathrm{C} \pm 2{ }^{\circ} \mathrm{C}$ for 3 minute. The release of penicilloic acid was determined by adding $125 \mu \mathrm{l}$ of an aqueous solution containing $0.5 \%$ iodine $(w / v)$ and $1 \%$ potassium iodide $(w / v)$. Decolorization of the sample $(<3$ minutes) was considered a positive reaction. Qualitative detection of biofilm formation was studied by culturing the strains on Congo red agar (CRA) plates as described previously [20]. The media contained ZMB broth $\left(37 \mathrm{~g} / \mathrm{l}^{-1}\right)$, sucrose $(0.8 \mathrm{~g} /$ $\left.\mathrm{l}^{-1}\right)$, agar $\left(10 \mathrm{~g} / \mathrm{l}^{-1}\right)$, and Congo red stain $\left(0.8 \mathrm{~g} / \mathrm{l}^{-1}\right)$. The Congo red stain was prepared as a concentrated aqueous solution, autoclaved separately, and added to the media after the agar had cooled to $55^{\circ} \mathrm{C}$. CRA plates were inoculated with the isolates listed in Table 3 and incubated aerobically for 24 hours at $37^{\circ} \mathrm{C}$. After incubation, the pigmented colonies (black color) were considered as mucoid phenotype positive. The plasmids were isolated from overnight grown bacterial cultures by the rapid boiling method. The antibiotic stock solutions (HiMedia) of $1 \mathrm{mg} / \mathrm{l}^{-1}$ were prepared and filter sterilized using $0.2 \mu$ syringe filters (Millipore, India). The antibiotic resistance profile of each isolate was examined by Kirby-Bauer disk diffusion test according to the standard procedures outlined in the NCCLS guidelines [21]. To assess the cross-tolerance among chosen TBT-resistant bacteria, several heavy metals, viz. $\mathrm{Hg}, \mathrm{Ni}, \mathrm{Cd}, \mathrm{Sn}, \mathrm{Cu}, \mathrm{Pb}$, and $\mathrm{Zn}$, were used in the study. The cross-tolerance was checked by increasing the concentration of the respective metal in a stepwise manner with $50 \mu \mathrm{g} / \mathrm{ml}^{-1}$ of metal increased every time [13].

\subsection{Growth Behavior of Selected TBT-Resistant Bacterial Isolates}

To determine the growth profiles of selected TBT-resistant bacterial isolates, $1 \mathrm{ml}$ of exponential phase cultures and approximately $10^{6}$ cells $\mathrm{ml}^{-1}$ were inoculated in MSM supplemented with $3 \mathrm{mM}$ TBT and incubated at $37^{\circ} \mathrm{C} \pm 2$ and $250 \mathrm{rpm}$ for 72 hours (Orbitek incubator shaker). TBT stock solution was prepared in ethanol, and subsequently, a control was prepared using the same volume of ethanol to ensure the cell growth was solely supported by TBT. At 6-hour intervals, $1 \mathrm{ml}$ aliquot was withdrawn from the 
culture and optical density was monitored at $\mathrm{A}_{600} \mathrm{~nm}$, using a UVVis spectrophotometer (Biotek Instruments Inc., Winooski, VT). The strain which evidenced the highest TBT tolerance regarding growth yield was further chosen for molecular identification and phylogenic analysis.

\subsection{Molecular Identification}

Genomic DNA was isolated and the 16S rRNA gene was amplified by PCR (Eppendorf, Germany) using universal bacterial $16 \mathrm{~S}$ rRNA gene primers [22]. Followed by PCR amplification and subsequent sequencing analysis (Macrogen Inc.), the DNA sequence was compared for homology in the NCBI-BLAST database. The sequences of strain VBAK and associated taxa of TBT-resistant bacteria were aligned using Clustalw (http://www. ebi.eic.uk/clustalw). The evolutionary history for all aligned sequences was inferred using the maximum composite likelihood (MCL) method based on the Kimura two-parameter model [23]. The evolutionary analyses for the strain VBAK were conducted using MEGA5 software [24].

\subsection{TBT Degradation}

TBT degradation by Pseudomonas sp. VBAK was evaluated using a modified method described by Khanolkar et al. [25]. The isolate was exposed to $3 \mathrm{mM}$ TBT for 5 days in MSM medium at $28^{\circ} \mathrm{C}$ in an incubator shaker. One milliliter of broth of pure culture was exposed to TBT and was assayed for 0-96-hour time intervals. TBT degradation was determined as TBT in the medium, TBT adsorbed on surfaces of the cells, and TBT accumulated in the cells. The TBT degradation (\%) was calculated as follows: Amount of TBT degradation/Amount of initial TBT $\times 100$. Samples were centrifuged at $10,000 \mathrm{~g}$ and residual TBT in the medium was determined in the supernatant. The pellet was further washed with $1 \mathrm{ml}$ of $10 \mathrm{mM}$ EDTA solution for desorption of TBT from the cell surfaces and centrifuged once again. TBT adsorbed onto the cell surfaces was separated from this supernatant. The amount of intracellular accumulation of TBT was determined by measuring the content in the pellet and resuspended in PBS buffer, sonicated at $50 \mathrm{MHz}$ on ice, and the extracts were for further analysis.

\subsection{TBT Adsorption and Accumulation Studies}

The removal of TBT by Pseudomonas sp. VBAK was evaluated and exposed to $3 \mathrm{ppm}$ TBT for 5 days in MSM medium at $25^{\circ} \mathrm{C}$ in an incubator shaker. TBT removal was determined as metal in the medium, metal adsorbed on the surfaces of the cells, and metal accumulated in the cells. The concentration of TBT was measured by an atomic absorption spectrophotometer. The TBT removal rate (\%) was calculated as follows: Amount of removed TBT/Amount of initial TBT $\times 100$. Samples were centrifuged at 10,000 rpm and residual TBT in the medium was determined in the supernatant. The pellet was further washed with $1 \mathrm{ml}$ of $10 \mathrm{mM}$ EDTA solution for desorption of TBT from the cell surfaces and centrifuged. TBT adsorbed onto the cell surfaces were separated from this supernatant. The amount of intracellular accumulation of TBT was determined by measuring the TBT content in the pellet and resuspended and sonicated at $50 \mathrm{MHz}$ on ice in $1 \mathrm{ml}$ of $1 \mathrm{~N} \mathrm{HNO}_{3}$ using an atomic absorption spectrophotometer.

\subsection{TBT Degradation by Thin-Layer Chromatography}

TBT degradation was carried out using a modified thin-layer chromatography (TLC) method as previously described by Roy and Bhosle [14]. The TLC plate $(0.5 \mathrm{~mm})$ was prepared and kept in the oven for activation and developed in petroleum ether $\left(40^{\circ} \mathrm{C}-60^{\circ} \mathrm{C}\right)$ and acetic acid $(9.5: 0.5)$ solvent system. The plate was removed and exposed to iodine vapor for visualization of the spots. One-way analysis of variance (ANOVA) was used to analyze data among treatments, followed by the Dunnett's test to discriminate significant differences between treatments and control. The data are expressed as mean \pm standard deviation (SD) with each assay conducted in triplicate. The significance level was inferred at $p<0.05$ for all statistical tests used.

\section{RESULTS AND DISCUSSION}

This work presented a potential tool to accelerate TBT removal from contaminated ports by using marine bacteria. It was demonstrated that Pseudomonas sp. strain VBAK was able to tolerate extremely high concentrations of TBT and have potential application in bioremediation of contaminated waters. Visakhapatnam port lies on the east coast of India, roughly halfway between Chennai and Kolkata, and is one of the largest and busiest ports in India. Since the paint scrapings in sediments are the primary source of bacteria, we enriched the samples by supplementing the media with TBT and determined the concentrations of TBT resistance in bacteria, along with other physical and chemical parameters, in the sediments and water column. This port was selected because of its highest marine traffic and ship-related activities. Also, it is expected to have distinct physicochemical properties and different bacterial communities at the port vicinity. Some physicochemical variables of the samples were ascertained from the port where TBT-tolerant bacteria were isolated. During the sampling period, the temperatures in the port ranged from $32^{\circ} \mathrm{C}$ to $34.3^{\circ} \mathrm{C}$ from February to March 2015 . The $\mathrm{pH}$ values constantly remained between 7.8 and 8.0 ; salinity ranged between $31.03 \%$ and $32.04 \%$; alkalinity ranged between 2.26 and 2.38 meq..$^{-1}$; chlorinity ranged between 11.83 and $16.44 \mathrm{ml}^{-1}$; dissolved oxygen ranged between 2.24 and $3.52 \mu \mathrm{mol} . \mathrm{dm}^{-3} / \mathrm{l}$; organic carbon ranged between $1.2 \%$ and $5.0 \%$; inorganic contents, viz. phosphates ranged between 0.64 and $1.3 \mu \mathrm{M}$, nitrates between 2.48 and $3.84 \mu \mathrm{M}$, and nitrites between 0.58 and $0.84 \mu \mathrm{M}$, respectively (data not shown).

The enumeration of the total bacterial counts is most crucial for estimating the TBT resistance in the harbor. The total bacterial counts varied from $53 \times 10^{6}$ to $144 \times 10^{6} \mathrm{CFU} \mathrm{m}^{-1}$ when plated on ZMB only. However, the viable counts on ZMB $+1 \mathrm{mM}$ TBT and MSM $+1 \mathrm{mM}$ TBT ranged from $48 \times 10^{4}$ to $125 \times 10^{4} \mathrm{CFU}$ $\mathrm{ml}^{-1}$ and $32^{-1} 01 \mathrm{CFU} \mathrm{ml} \mathrm{m}^{-1}$, respectively. It is interesting to note that the total viable counts in $\mathrm{ZMB}+2 \mathrm{mM}$ TBT and $\mathrm{MSM}+2$ $\mathrm{mM}$ TBT ranged between $24 \times 10^{4}$ and $86 \times 10^{4}$ and $12.5-55 \mathrm{CFU}$ $\mathrm{ml}^{-1}$, respectively (Table 1). Statistically, the total bacterial counts varied across 10 sampled sites as validated by one-way ANOVA and Dunnett's test. It was observed for all sampled locations that, with an increase in the concentrations of TBT, the number of $\mathrm{CFU} \mathrm{ml} \mathrm{m}^{-1}$ decreased significantly and the percentage of resistant bacteria was lower compared to controls. The total viable counts 
Table 1: Enumeration of total viable counts of TBT-resistant bacterial isolates from Vishakhapatnam shipping harbor.

\begin{tabular}{|c|c|c|c|c|c|c|c|c|}
\hline \multirow[t]{2}{*}{ Sampling sites } & \multirow[t]{2}{*}{$\begin{array}{c}\text { Date of } \\
\text { Sampling }\end{array}$} & \multirow[t]{2}{*}{ Latitude } & \multirow[t]{2}{*}{ Longitude } & \multirow[t]{2}{*}{$\begin{array}{c}\text { ZMBA (CFU } \\
\left.\times 10^{\circ}\right) / \mathrm{ml} \pm \mathrm{SE}\end{array}$} & \multicolumn{2}{|c|}{$\begin{array}{c}\mathrm{ZMBA}+\mathrm{TBT} \\
\left(\mathrm{CFU} \times \mathbf{1 0}^{4}\right) / \mathrm{ml} \pm \mathrm{SE}\end{array}$} & \multicolumn{2}{|c|}{$\begin{array}{c}\text { MSMA + TBT }(\mathrm{CFU}) / \\
\mathrm{ml} \pm \mathrm{SE}\end{array}$} \\
\hline & & & & & $\begin{array}{c}\text { ZMBA + } \\
1 \text { mM TBT }\end{array}$ & $\begin{array}{c}\text { ZMBA+ } \\
2 \text { mM TBT }\end{array}$ & $\begin{array}{c}\text { MSMA + } \\
1 \text { mM TBT }\end{array}$ & $\begin{array}{c}\text { MSMA + } \\
2 \text { mM TBT }\end{array}$ \\
\hline Over berth & $15 / 02 / 2015$ & $15^{\circ} 27^{\prime} 010^{\prime \prime} \mathrm{N}$ & $73^{\circ} 49^{\prime} 080^{\prime \prime} \mathrm{E}$ & $71 \pm 4.8$ & $64 \pm 5.4$ & $50 \pm 3.1$ & $57 \pm 9.0$ & $36 \pm 8.7$ \\
\hline Berth wall & $20 / 02 / 2015$ & $15^{\circ} 27^{\prime} 328^{\prime \prime} \mathrm{N}$ & $73^{\circ} 49^{\prime} 842 \mathrm{E}$ & $80 \pm 6.4$ & $73 \pm 6.2$ & $28 \pm 7.2$ & $45 \pm 1.5$ & $24 \pm 3.8$ \\
\hline Fishing jetty & $22 / 02 / 2015$ & $15^{\circ} 27^{\prime} 628^{\prime \prime} \mathrm{N}$ & $73^{\circ} 49^{\prime} 802 \mathrm{E}$ & $65 \pm 2.5$ & $58 \pm 9.1$ & $44 \pm 3.9$ & $55 \pm 5.3$ & $30 \pm 7.4$ \\
\hline Garbage skip & $24 / 02 / 2015$ & $15^{\circ} 27^{\prime} 603^{\prime \prime} \mathrm{N}$ & $73^{\circ} 49^{\prime} 760 \mathrm{E}$ & $53 \pm 4.1$ & $48 \pm 5.9$ & $35 \pm 3.4$ & $45 \pm 1.5$ & $30 \pm 7.4$ \\
\hline Paint yard & $27 / 02 / 2015$ & $15^{\circ} 27^{\prime} 642^{\prime \prime} \mathrm{N}$ & $73^{\circ} 49^{\prime} 780^{\prime \prime} \mathrm{E}$ & $144 \pm 7.3$ & $125 \pm 1.4$ & $86 \pm 5.2$ & $101 \pm 303$ & $55 \pm 3.4$ \\
\hline Sediment & $28 / 02 / 2015$ & $15^{\circ} 27^{\prime} 703^{\prime \prime} \mathrm{N}$ & $73^{\circ} 49^{\prime} 985^{\prime \prime} \mathrm{E}$ & $78 \pm 4.8$ & $64 \pm 1.2$ & $26 \pm 5.2$ & $96 \pm 12.0$ & $27 \pm 30.4$ \\
\hline Jetty repair & $04 / 03 / 2015$ & $15^{\circ} 27^{\prime} 710^{\prime \prime} \mathrm{N}$ & $73^{\circ} 49^{\prime} 982^{\prime \prime} \mathrm{E}$ & $112 \pm 3.8$ & $95 \pm 5.8$ & $82 \pm 3.7$ & $74 \pm 1.6$ & $45 \pm 10.5$ \\
\hline Ship wall & $10 / 03 / 2015$ & $15^{\circ} 27^{\prime} 726^{\prime \prime} \mathrm{N}$ & $73^{\circ} 49^{\prime} 989^{\prime \prime} \mathrm{E}$ & $126 \pm 2.0$ & $106 \pm 6.3$ & $76 \pm 5.4$ & $93 \pm 5.4$ & $55 \pm 2.8$ \\
\hline Dry dock & $15 / 03 / 2015$ & $15^{\circ} 27^{\prime} 706^{\prime \prime} \mathrm{N}$ & $73^{\circ} 49^{\prime} 980^{\prime \prime} \mathrm{E}$ & $67 \pm 6.1$ & $57 \pm 3.4$ & $24 \pm 3.8$ & $32 \pm 6.7$ & $12.5 \pm 2.5$ \\
\hline Winch house & $15 / 03 / 2015$ & $15^{\circ} 27^{\prime} 718^{\prime \prime} \mathrm{N}$ & $73^{\circ} 49^{\prime} 996^{\prime \prime} \mathrm{E}$ & $81 \pm 5.8$ & $64 \pm 6.3$ & $33 \pm 3.1$ & $67 \pm 2.0$ & $23 \pm 6.0$ \\
\hline
\end{tabular}

were determined to be very high at the port's paint yard, i.e., $125 \pm$ $1.4 \times 10^{4} \mathrm{CFU} \mathrm{ml}^{-1}$ in $\mathrm{ZMB}+1 \mathrm{mM}$ and $86 \pm 5.2 \times 10^{4}$ in $\mathrm{ZMB}+$ $2 \mathrm{mM}$ TBT respectively. However, a similar elevated response was observed in the total viable counts when enumerated in presence of MSM + TBT (Table 1). In the preliminary screening, the natural bacterial isolates were resistant to up to $2 \mathrm{mM}$ of TBT. These results exemplify the possibility of this port having the highest levels of TBT and DBT. There could also be a strong correlation between the occurrence of TBT-resistant bacteria and the levels of TBT in port sediments after paint scrapings.

The colonies grown on ZMB containing $1 \mathrm{mM}$ TBT were obtained after the enrichment culture method. A total of 205 isolates resistant to $1 \mathrm{mM}$ TBT were isolated from 10 sampling sites and used in subsequent experiments. Fourteen morphologically different TBT-resistant strains obtained from the primary screening were designated as VSK74, VSK104, VSK114, VBAK, VSK21, VSK46, VSK59, VSK78, VSK81, VSK89, VSK92, VSK182, VSK218, and VSK221. These isolates were selected for morphological, physiological, and biochemical tests, viz. growth in $\mathrm{NaCl}, \beta$-lactamase production, phenotype of strains on CRA plates, biofilm production, presence of plasmids, resistance to antimicrobials, and cross-tolerance to heavy metals. The strains grown on CRA medium resulted in two colony morphotypes with different colors (pink and black). Among the 14 strains tested in this study, only 5 strains were mucoid biofilm producers (VSK74, VSK114, VBAK, VSK78, and VSK221) characterized by black colonies, and the remaining strains were considered as non-biofilm producers (Table 2). All strains were Gram-negative facultative anaerobes, motile rods, and exhibited salt requirement up to $3 \%-6 \% \mathrm{NaCl}$. In this study, it was also observed that all the selected TBT-resistant isolates contained high molecular weight plasmids $>4 \mathrm{~kb}$ (data not shown). Most of the isolates were able to cleave the $\beta$-lactam ring and produce penicilloic acid. The results of the antibiotic sensitivity tested by the disk diffusion method are summarized in Table 2. Multiple resistances to ampicillin and cephalosporins coupled to cephalothin and/or TET/OTET were observed. The result was summarized for seven different metal ions, i.e., $\mathrm{Hg}$, $\mathrm{Cd}, \mathrm{Ni}, \mathrm{Sn}, \mathrm{Cu}, \mathrm{Pb}$, and $\mathrm{Zn}$. Strain VBAK showed maximum resistance against $\mathrm{Zn}$ and $\mathrm{Cu}$ at a concentration of $5 \mathrm{mg} / \mathrm{ml}^{-1}$ and the order of resistance regarding the metal concentration was $\mathrm{Zn}>\mathrm{Cu}>\mathrm{Ni}>\mathrm{Pb}>\mathrm{Sn}>\mathrm{Cd}>\mathrm{Hg}$. All strains were resistant to at least five out of seven heavy metals tested; suggesting that cross-tolerance to other heavy metals may be associated with resistance to TBT. Cadmium resistance was observed in $71 \%$ of the strains tested, whereas $35 \%$ of resistance was detected in $\mathrm{Hg}$. However, multiple resistances to $\mathrm{Ni}, \mathrm{Sn}, \mathrm{Pb}, \mathrm{Cu}$, and $\mathrm{Zn}$ were observed in the isolates (Table 2).

Our results indicate that the growth of TBT-resistant strains was inversely related to the concentration of TBT in the culture medium (Fig. 1). Markedly, the growth study of the selected isolates showed an initial lag for 10 hours, followed by an extended exponential phase. To determine the optimum concentration level of TBT for the growth of bacterial isolates, individual isolates were grown separately in MSM with different concentrations of TBT ranging from 1 to $3 \mathrm{mM}$. The higher concentration of TBT, i.e., $4 \mathrm{mM}$, showed growth with an extended lag phase of more than 18 hours (data not shown). Hence, the optimum level for growth of the isolates was considered to be $3 \mathrm{mM}$ TBT in MSM broth (Fig. 1). Among the 14 selected isolates, strain VBAK (identified as Pseudomonas sp) evidenced the highest growth yield in the presence of $3 \mathrm{mM}$ TBT (Fig. 1). It was further observed that at a higher TBT concentration of $3 \mathrm{mM}$, the VBAK culture reached an optical density $\mathrm{A}_{600} \mathrm{~nm}$ of 1.8 after 48 hours. Interestingly, the control flask with MSM + ethanol 


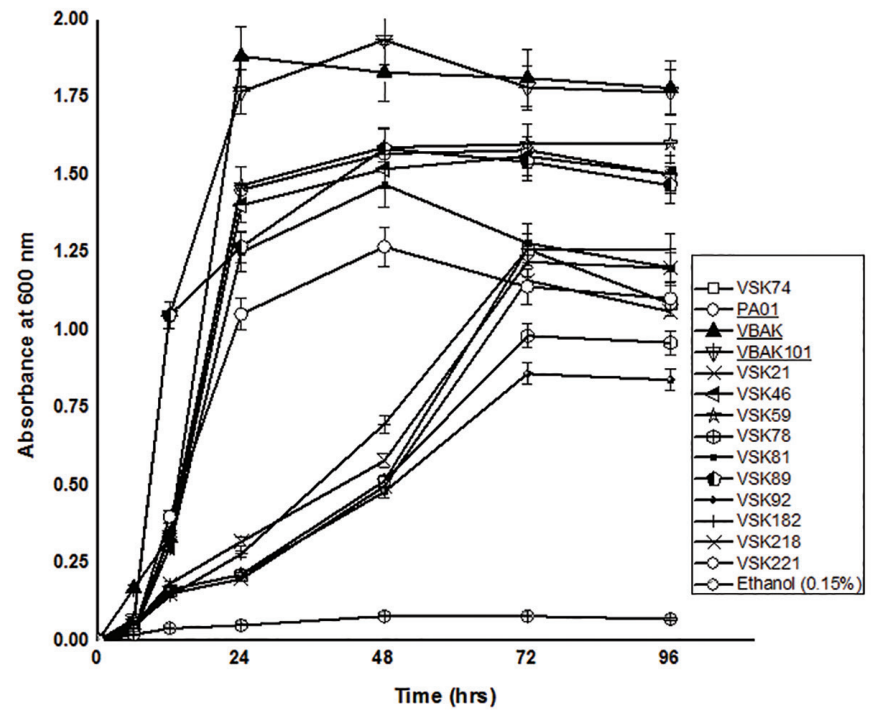

Figure 1: Growth profiles for selected TBT resistant bacterial isolates in $3 \mathrm{mM}$ TBT as sole carbon source.

$(0.15 \%, v / v)$ did not support the growth of isolates, suggesting that strain VBAK utilized TBT as the sole carbon source for its metabolic and physiological activities. Subsequently, based on maximum TBT tolerance by strain VBAK, 16S rRNA gene was identified as Pseudomonas sp. and the sequence is available on GenBank with an accession number KF551879. Figure 2 shows the MCL phylogenetic tree based on 16S rRNA gene sequences of TBT-resistant strain VBAK isolated in this study and few other TBT-resistant microorganisms previously reported in the literature. The MCL showed that strain VBAK formed a coherent

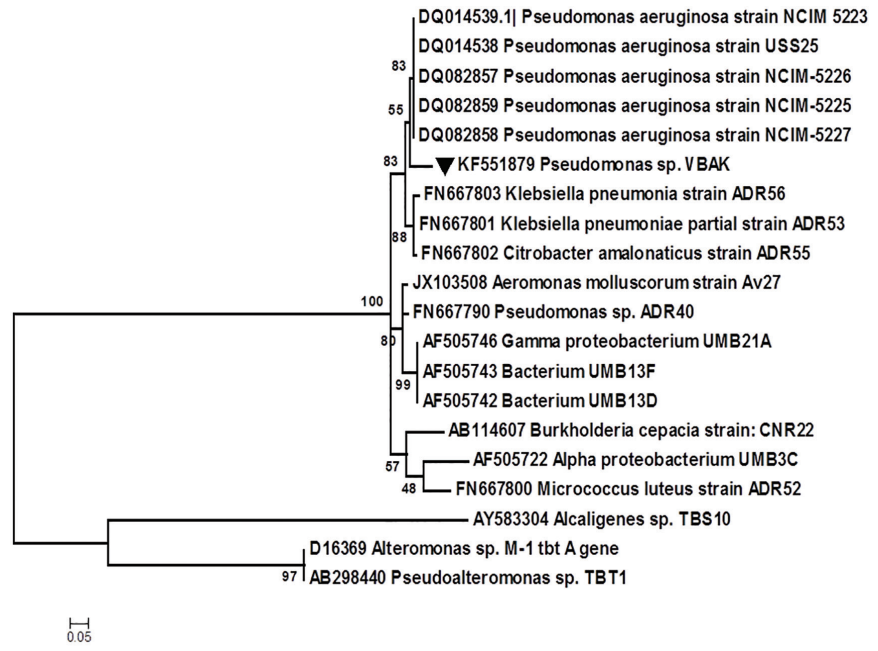

Figure 2: Unrooted maximum likelihood method phylogenetic tree based on 16S rRNA gene of Pseudomonas strain VBAK.

cluster with the clad that comprised Pseudomonas genus to be its closest phylogenetic neighbor.

Based on the optimum resistance limit of the isolate, $3 \mathrm{mM}$ TBT concentration was selected. Pseudomonas strain VBAK cells were exposed to $3 \mathrm{mM}$ TBT for 5 days incubation in MSM medium, and these showed differing abilities for adsorption and accumulation. The results obtained for the TBT adsorbed onto the cell surfaces and intracellular accumulated are expressed as a percentage of depletion after 96 hours of incubation are shown in Figure 3. At the end of 72 hours of incubation, the strain VBAK adsorbed $75 \%$ of TBT onto the cell surfaces and accumulated $15 \%$ of TBT intracellular (Fig. 3). The proportions of the remaining TBT in the

Table 2: Physiological and biochemical characteristics of selected TBT-resistant isolates ( $\beta$-lactamase, plasmid, biofilm production, antibiotic resistance profiles, and cross-tolerance to heavy metals.

\begin{tabular}{|c|c|c|c|c|c|c|c|c|}
\hline $\begin{array}{l}\text { Strain } \\
\text { ID }\end{array}$ & $\begin{array}{c}\text { Growth } \\
\text { in } 3 \% \\
\mathrm{NaCl}\end{array}$ & $\begin{array}{c}\text { Growth } \\
\text { in } 6 \% \\
\mathrm{NaCl}\end{array}$ & $\begin{array}{l}\beta \text {-lactamase } \\
\text { production }\end{array}$ & $\begin{array}{c}\text { Biofilm } \\
\text { production }\end{array}$ & $\begin{array}{l}\text { Phenotype } \\
\text { of strain on } \\
\text { CRA plates }\end{array}$ & $\begin{array}{l}\text { Presence } \\
\text { of plasmid }\end{array}$ & Resistance antimicrobials & $\begin{array}{l}\text { Cross tolerance to } \\
\text { heavy metals }\end{array}$ \\
\hline VSK21 & + & + & + & + & Pink & + & AMP, CFP, TET, AK, & $\mathrm{Ni}, \mathrm{Cd}, \mathrm{Sn}, \mathrm{Pb}, \mathrm{Cu}, \mathrm{Zn}$ \\
\hline VSK46 & + & - & + & + & Pink & + & AMP, CFP, CF & $\mathrm{Ni}, \mathrm{Cd}, \mathrm{Sn}, \mathrm{Pb}, \mathrm{Cu}, \mathrm{Zn}$ \\
\hline VSK59 & + & - & + & + & Pink & + & AMP, CFP, CF & $\mathrm{Ni}, \mathrm{Cd}, \mathrm{Sn}, \mathrm{Pb}, \mathrm{Cu}, \mathrm{Zn}$ \\
\hline VSK74 & + & - & ++ & ++ & Black & + & AMP, CFP, CF, OTET, AK, NA & $\mathrm{Hg}, \mathrm{Ni}, \mathrm{Cd}, \mathrm{Sn}, \mathrm{Pb}, \mathrm{Cu}, \mathrm{Zn}$ \\
\hline VSK78 & + & + & ++ & ++ & Black & + & AMP, CF, AK, TMP, KAN, CLP & $\mathrm{Hg}, \mathrm{Ni}, \mathrm{Cd}, \mathrm{Sn}, \mathrm{Pb}, \mathrm{Cu}, \mathrm{Zn}$ \\
\hline VSK81 & + & + & + & + & Pink & + & AMP, CFP, CF, OTET, TMP & $\mathrm{Ni}, \mathrm{Cd}, \mathrm{Sn}, \mathrm{Pb}, \mathrm{Cu}, \mathrm{Zn}$ \\
\hline VSK89 & + & + & + & + & Pink & + & AMP, CF, AK, TMP & $\mathrm{Ni}, \mathrm{Cd}, \mathrm{Sn}, \mathrm{Pb}, \mathrm{Cu}, \mathrm{Zn}$ \\
\hline VSK92 & + & + & + & + & Pink & + & AMP, CFP, CF & $\mathrm{Ni}, \mathrm{Cd}, \mathrm{Sn}, \mathrm{Pb}, \mathrm{Cu}, \mathrm{Zn}$ \\
\hline VSK101 & + & + & ++ & ++ & Black & + & AMP, CFP, CF & $\mathrm{Ni}, \mathrm{Cd}, \mathrm{Sn}, \mathrm{Pb}, \mathrm{Cu}, \mathrm{Zn}$ \\
\hline VSK114 & + & - & ++ & ++ & Black & + & AMP, CFP, CF, OTET, TMP & $\mathrm{Hg}, \mathrm{Ni}, \mathrm{Cd}, \mathrm{Sn}, \mathrm{Pb}, \mathrm{Cu}, \mathrm{Zn}$ \\
\hline VBAK & + & + & +++ & +++ & Black & + & AMP, CF, AK, TMP & $\mathrm{Hg}, \mathrm{Ni}, \mathrm{Cd}, \mathrm{Sn}, \mathrm{Pb}, \mathrm{Cu}, \mathrm{Zn}$ \\
\hline VSK182 & + & + & + & + & Pink & + & AMP, CFP, CF, OTET, AK, NA & $\mathrm{Ni}, \mathrm{Cd}, \mathrm{Sn}, \mathrm{Pb}, \mathrm{Cu}, \mathrm{Zn}$ \\
\hline VSK218 & + & + & + & + & Pink & + & AMP, CFP, CF, OTET, AK, NA & $\mathrm{Ni}, \mathrm{Cd}, \mathrm{Sn}, \mathrm{Pb}, \mathrm{Cu}, \mathrm{Zn}$ \\
\hline VSK221 & + & + & + & + & Pink & + & AMP, CF, AK, TMP, CLP, KAN & $\mathrm{Hg}, \mathrm{Ni}, \mathrm{Cd}, \mathrm{Sn}, \mathrm{Pb}, \mathrm{Cu}, \mathrm{Zn}$ \\
\hline
\end{tabular}



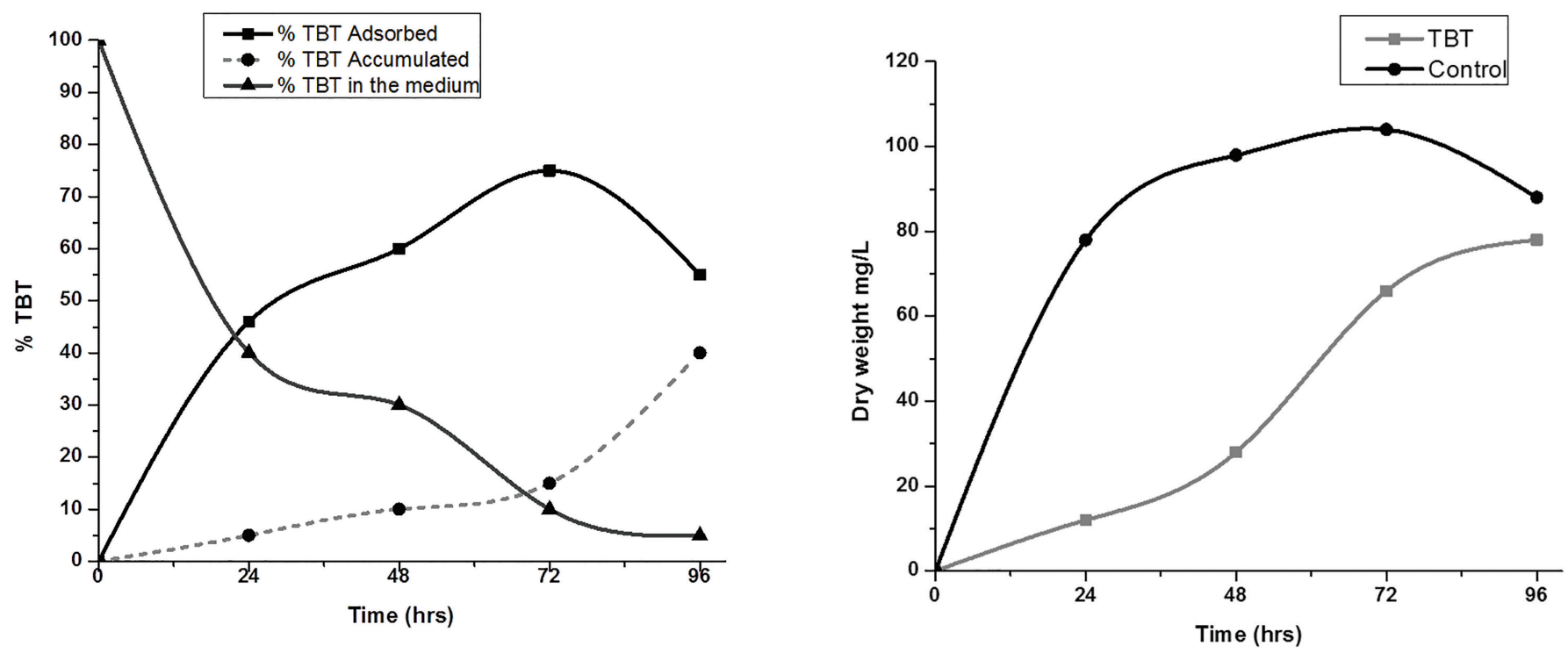

Figure 3 (a and b): TBT removed by strain VBAK ( $y$-axis), TBT in the medium ( $x$-axis), and TBT accumulated and adsorbed.

medium were determined as $10 \%$. It is interesting to note that the cells adsorbed $55 \%$ and accumulated $40 \%$ at the end of 96 hours of incubation. Taking into account the results obtained, it can be observed that the accumulation of TBT increases gradually in the late log phase to the stationary phase of growth, resulting in high TBT adsorption and accumulation efficiencies (Fig. 4). Since the accumulation efficiency of VBAK was low (Fig. 3), but its maximum resistance limit was high, at the level of $3 \mathrm{mM}$ (Fig. 2), it

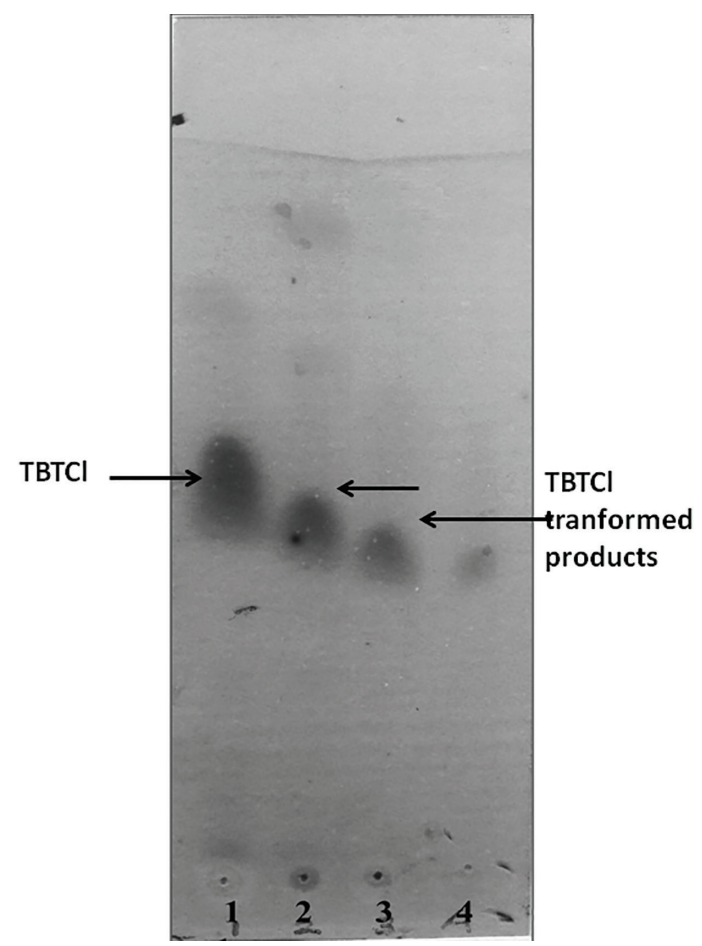

Figure 4: TBT degradation by strain VBAK (TLC profiles: Lane 1, crude TBT; Lane 2, ethanol extracts after 18 hours; Lane 3, after 36 hours; and Lane 4, after 56 hours). suggested that the strain might have an efflux mechanism with the help of which it is releasing the TBT in its reduced form, i.e., DBT. The ability of Pseudomonas strain VBAK harvested at different culture time intervals to degrade $3 \mathrm{mM}$ TBT showed a good agreement with its biomass produced at the same culture phase. Moreover, TBT $3 \mathrm{mM}$ concentration strongly inhibited the growth in terms of dry cell weight $(\mathrm{mg} / \mathrm{l})$ of the tested strain during the first 24 hours of incubation (Fig. 3). Additionally, an increase in the concentration of degradation byproducts was correlated with bacterial growth (Fig. 3). The adsorption of TBT onto the cell surface suggests that interactions of TBT with functional groups on the extracellular polysaccharides of the cell surface.

It was interesting to note that the TLC profile of the degradation product noticeably revealed aspects with reduction of TBT and gradual transformation into dibutyltin chloride (DBT; Fig. 4). Our results clearly showed that the TLC profile of the cell pellet extract obtained after 18, 36, and 56 hours of incubation revealed the presence of the transformed product which may be attributed to the presence of DBT. The $R f$ values of TBT and the transformed compound were 0.8 (solvent front $=16.5 \pm 2$, TBT $9.1 \pm 1.0$ ) and 0.7 (solvent front $=16.5 \pm 2$, product $6.8 \pm 2$ ), respectively.

Butyltins in underdeveloped nations are monitored in a limited way, and the usage of TBT in most places has yet to be synchronized, but there are essentially no marine biocides reports [6]. Recent observations of Garg et al. [7] also lend experimental support to such view that Vishakhapatnam port was reported to be the second most polluted port in India. Surprisingly, the microorganisms could be considered potential bioremediation tools for the removal of TBT from the contaminated environment. Nevertheless, only a limited number of marine bacteria were investigated for biodegradation of TBT in India. This study carries out the first report on the isolation of TBT-resistant bacteria from Vishakhapatnam port. Our results also suggest that the TBT-resistant bacteria are very common in this harbor and hence the possibility of active biotransformation and biodegradation processes at the port sediments and water 
columns. Despite the heavy sea traffic and shipyard activities at the Indian ports, the research reports are limited on the seasonal distribution of butyltins in water and sediments in Indian ports $[5,7,26,27]$. To the best of our knowledge, there are no reports on the occurrence of TBT-utilizing bacteria as the sole carbon source from the east coast of India. Physicochemical and environmental factors may also selectively alter the resistance of microorganisms in polluted aquatic systems [1]. However, previous studies revealed that increased $\mathrm{NaCl}$ concentrations reduced the toxic effect of TBT by exerting an osmotic pressure in intracellular membrane composition [29]. Likewise, Harino et al. [30] observed that warmer ambient temperatures and intense sunlight are responsible for a higher TBT degradation index. Due to low water solubility, however, TBT preferentially binds to suspended organic matter released from marine sediments and also exhibits lipophilic properties, which means that TBT levels at the port will be subjective to concentrations of organic carbon [8].

It is also apparent in our study that a high percentage of organic carbon and phosphates observed at the port's paint yard implies that it may have a unique tendency to bind TBT by adsorption/ desorption mechanism and metabolize TBT as the sole carbon source. Rajendran et al. [26] similarly reported a good correlation between organic carbon and butyltins in the sediments from Chennai and Tuticorin ports. The number of CFU ml-1 in the media supplemented with and without TBT is significantly different, hence supporting the fact that media with TBT limited the growth of organisms moderately. In all sampled locations, there was a significant decrease in the number of CFU ml-1 in $1 \mathrm{mM}$ TBT, which revealed TBT-resistant bacteria isolated were concentrationdependent. However, at $2 \mathrm{mM}$ TBT, the growth was significantly affected with a decline in $\mathrm{CFU} \mathrm{ml} \mathrm{m}^{-1}$ with the percentage of $50 \%$ when compared to the control, implying that this concentration is considered toxic to the cells. It is also interesting to note that $11 \%$ of the bacterial population is resistant to $1 \mathrm{mM}$ of TBT as it utilizes carbon as the sole source. On the occurrence of TBT resistance in environmental bacteria, Suzuki et al. [12] reported that TBT exerts selective pressure on seawater microbes. In a recent report, Suehiro et al. [10] showed up to $34 \%$ of the natural population resistant to TBT in the Mekong River wherein the occurrence of TBT and TBT-tolerant bacteria was unrelated. Among the sampled locations, the dry dock had the lowest CFU ml $\mathrm{m}^{-1}$ in the control, while much higher total bacterial counts were obtained at the port's paint yard. Statistically significant differences in viable counts were observed for all locations between selective media and control groups (Dunnett's test, $p<0.05$ ).

In this context, a study was conducted to investigate whether bacterial resistances to $\beta$-lactamase often result in the inactivation of antibiotics by producing $\beta$-lactamase. However, previous studies had similarly reported the production of $\beta$-lactamase by marine bacteria with high resistance to $\beta$-lactam antibiotics [28]. In the resistance to TBT and perhaps transferring the TBT resistance across bacteria, the plasmids play an essential role [31]. One of the TBT pathways is commonly referred to as the RND effect system [32]. In addition to multidrug resistance, TBT resistance has been combined with multiple antibiotic resistances, heavy metal resistance, and other pollutants $[10,12,23]$. The TLC profile showed the strain VBAK may have an inherent biochemical and/ or genetic mechanism to degrade TBT into less toxic compounds such as DBT. The degradation of TBT in the natural environment appears to be mainly controlled by microbial degradation, rather than physical and chemical action (Fig. 4).

A wide variety of Pseudomonas species from Indian ports [14,15] are microorganisms able to absorb and resist TBT. The fact that high levels of DBT in the port of Vishakhapatnam have an active role in photochemical or microbial degradation [8] can be related to the fact that TBT metabolizing bacteria are present in the current investigation. Notably, the use, for the first time in vitro, of TBT as a single carbon source by Pseudomonas sp. VBAK strain from Vishakhapatnam harbor was demonstrated to be less hazardous. The TBT-resistant culture isolation growth behavior represents the toxicity reduction methods into sublethal levels. Strikingly, the potential of these bacteria as bioremediation agents was evaluated through microbiological assays using the Pseudomonas species as model organism $[33,35,36]$. Kinetics modeling of TBT toxicity on the growth of Bacillus stearothermophilus was studied in a recent report [37]. Degradation capability of novel haloalkaliphilic TBT chloride-resistant bacteria from butyltin-polluted site confirmed that the TBTB-permease-like gene contributes to TBT resistance [38]. Various methods for the survival of TBT bacteria, such as efflux pumping [32], biosorption and bioaccumulation [1,34], adsorption [18], and detoxifying [2], have also been suggested.

\section{CONCLUSION}

High exposure to TBT has cytotoxic effects on cellular metabolism and physiology and is inhibitory for the cells. In addition, the organism can use TBT, either inducible or constituent enzymes, in a lower quantity or by converting it to less toxic molecules, leading to a protracted lag period during development. In comparison to other Gram-positive or Gram-negative bacterial strains of TBT, i.e., greater TBT tolerances, viz. Bacillus, Alcaligenes, Alteromonas, Vibrio, and Pseudomonas, since it is well known that these isolates could only tolerate up to $100 \mu \mathrm{M}$ TBT. It is, therefore, obvious that TBT resistance mechanisms are unique, allowing bacteria to evolve innate mechanisms for the treatment of TBT stress in certain conditions. Nevertheless, the biochemical and genetic system and incidence of TBTresistant bacterium should be clarified and additional monitoring and experimental research should be conducted.

\section{ACKNOWLEDGMENTS}

The authors are thankful to DST-SERB for providing financial assistance to Mr. B. Anand Kumar (JRF) under Grant No: SR/FT/ LS-129/2011, Govt. of India, New Delhi.

\section{AUTHORS' CONTRIBUTIONS}

All authors made considerable contributions to the conception, design, acquisition of data, and analysis and interpretation of the data. They took part in drafting the article or revising it critically for important intellectual content; agreed to submit it to the current journal; gave final approval for the version to be published; and agreed to be accountable for all aspects of the work. 


\section{CONFLICT OF INTEREST}

The authors declare that they do not have any conflict of interests.

\section{ETHICAL APPROVAL}

Not applicable for this work.

\section{REFERENCES}

1. White, JS, Tobin JM. Role of speciation in organotin toxicity to the yeast Candida maltosa. Environ Sci Technol 2004;38:3877-84; http:/ doi.org/10.1021/es030099k

2. Gadd GM Microbial interactions with tributyltin compounds: detoxification, accumulation, and environmental fate. Sci Total Environ 2000;258:119-27; http://doi.org/10.1016/S0048-9697(00)00512-X

3. Guo S, Qian L, Shi H, Barry T, Cao Q, Liu J. Effects of tributyltin (TBT) on Xenopus tropicalis embryos at environmentally relevant concentrations. Chemosphere 2010;79:529-533; http://doi. org/10.1016/j.chemosphere.2010.02.021

4. Blanca AL. Environmental levels, toxicity and human exposure to tributyltin (TBT)-contaminated marine environment. A review. Environ Int 2008;34:292-308; http://doi.org/10.1016/j.envint.2007.09.005

5. Sonak S, Pangam P, Giriyan A, Hawaldar K. Implications of the ban on organotins for protection of global coastal and marine ecology. J Environ Manage 2009;90:S96-108; http://doi.org/10.1016/j. jenvman.2008.08.017

6. Mukherjee A, Mohan Rao KV, Ramesh US. Predicted concentrations of biocides from antifouling paints in Visakhapatnam Harbour. J Environ Manage 2009;90:S51-9; http://doi.org/10.1016/j. jenvman.2008.07.018

7. Garg A, Meena RM, Jadhav S, Bhosle NB. Distribution of butyltins in the waters and sediments along the coast of India. Mar Pollut Bull 2011;62:423-31; http://doi.org/10.1016/j.marpolbul.2010.12.003

8. Garg A, Meena RM, Bhosle NB. Distribution of butyltins in waters and sediments of the Mandovi and Zuari estuaries, west coast of India. Environ Monit Assess, 2010;165:643-51. Available via https://link. springer.com/article/10.1007/s10661-009-0975-9

9. Fukagawa T, Konno S, Takama K, Suzuki S. Occurrence of tributyltin (TBT) and methyl mercury tolerant bacteria in natural seawater to which TBT was added. J Mar Biotechnol 1994;1(4):211-4; Available via https://www.ncbi.nlm.nih.gov/pmc/articles/PMC183113/

10. Suehiro F, Mochizuki H, Nakamura S, Iwata H, Kobayashi T, Tanabe $\mathrm{S}$, et al. Occurrence of tributyltin (TBT)-resistant bacteria is not related to TBT pollution in Mekong River and coastal sediment: With a hypothesis of selective pressure from suspended solid. Chemosphere 2007;68:1459-64; http://doi.org/10.1016/j.chemosphere.2007.03.033

11. Grandlic J, Geib I, Pilon R, Sandrin T. Lead pollution in a large, prairie-pothole lake (Rush Lake, WI, USA): effects on abundance and community structure of indigenous sediment bacteria. Environ Pollut 2006;144:119-26; http://doi.org/10.1016/j.envpol.2005.12.029

12. Suzuki S, Fukagawa T, Takama K. Occurrence of tributyltin-tolerant bacteria in tributyltin-or cadmium-containing seawater. Appl Environ Microbiol 1992;58:3410-2; http://doi.org/10.1128/aem.58.10.34103412.1992

13. Roy U, Nair D. Biodiversity of organotin resistant Pseudomonas from west coast of India. Ecotoxicol 2007;16:253-61. Available via https:// link.springer.com/article/10.1007/s10646-006-0125-x

14. Roy U, Bhosle S. Microbial transformation of tributyltin chloride by Pseudomonas aeruginosa strain USS25 NCIM-5224. Appl Organomet Chem 2006;20:5-11; http://doi.org/10.1002/aoc.997

15. Sampath R, Venkatakrishnan H, Ravichandran V, Chaudhury RR. Biochemistry of TBT-degrading marine pseudomonads isolated from Indian coastal waters. Water Air Soil Pollu 2012;223:99-106. Available via https://link.springer.com/article/10.1007/s11270-0110842-5
16. Grasshoff, K., Kremling, K., \& Ehrhardt, M. (Eds.). (2009). Methods of seawater analysis. John Wiley \& Sons.

17. Harji R, Bhosle NB, Garg A, Sawant SS, Venkat K. Sources of organic matter and microbial community structure in the sediments of the Visakhapatnam harbour, East coast of India. Chem Geol 2010;276:309-17; http://doi.org/10.1016/j.chemgeo.2010.06.015

18. Mimura H, Sato R, Furuyama Y, Taniike A, Yagi M, Yoshida $\mathrm{K}$, et al. Adsorption of tributyltin by tributyltin resistant marine Pseudoalteromonas sp. cells. Mar Pollut Bull 2008;57:877-82; http:// doi.org/10.1016/j.marpolbul.2008.03.029

19. Ottaviani D, Bacchiocchi I, Masini L, Leoni F, Carraturo A, Giammarioli $\mathrm{M}$, et al. Antimicrobial susceptibility of potentially pathogenic halophilic vibrios isolated from seafood. Int J Antimicrob Agents 2001;18:135-40; http://doi.org/10.1016/S0924-8579(01)00358-2

20. Jain A, Agarwal A. Biofilm production, a marker of pathogenic potential of colonizing and commensal staphylococci. J Microbiol Methods 2009;76:88-92; http://doi.org/10.1016/j.mimet.2008.09.017

21. NCCLS. Methods for dilution antimicrobial susceptibility tests for bacteria that grow aerobically approved standard. 5th edition, NCCLS document M7-A5 NCCLS, Wayne, PA, 2000. Available via https:/ ci.nii.ac.jp/naid/20001404762/

22. Pidiyar V, Kaznowski A, Narayan NB, Patole M, Shouche YS. Aeromonas culicicola $s p$. nov, from the midgut of Culex quinquefasciatus. Int J Sys Evol Microbiol 2002;52:1723-8; http:/ doi.org/10.1099/00207713-52-5-1723

23. Kimura M. A simple method for estimating evolutionary rates of base substitutions through comparative studies of nucleotide sequences. J Mol Evol 1980;16:111-20. Available via https://link.springer.com/ article/10.1007\%2FBF01731581

24. Tamura K, Peterson D, Peterson N, Stecher G, Nei M, Kumar S. MEGA5: molecular evolutionary genetics analysis using maximum likelihood, evolutionary distance, and maximum parsimony methods. Mol Bio Evol 2011;28:2731-9; http://doi.org/10.1093/molbev/msr121

25. Khanolkar DS, Dubey SK, Naik MM. Biotransformation of tributyltin chloride to less toxic dibutyltin dichloride and monobutyltin trichloride by Klebsiella pneumoniae strain SD9. Int Biodeter Biodegrad 2015;104:212-8; http://doi.org/10.1016/j.ibiod.2015.04.030

26. Rajendran RB, Tao H, Miyazaki A, Ramesh R, Ramachandran S Determination of butyl-, octyl- and tributylmonomethyltin compounds in a marine environment (Bay of Bengal, India) using gas chromatography-inductively coupled plasma mass spectrometry. J Environ Mon 2001;3:627-734. Available via https://pubs.rsc.org/en/ content/articlelanding $/ 2001 / \mathrm{em} / \mathrm{b} 106009 \mathrm{k} /$ unauth\#! divAbstract

27. Bhosle NB, Garg A, Harji R, Jadhav S, Sawant SS, Krishnamurthy $\mathrm{V}$, Anil AC Butyltins in the sediments of Kochi and Mumbai harbours, west coast of India. Environ Int 2006;32:252-8; http://doi. org/10.1016/j.envint.2005.08.020

28. McArthur JV, Tuckfield RC. Spatial patterns in antibiotic resistance among stream bacteria: effects of industrial pollution. Appl Environ Microbiol 2000;66:3722-6; http://doi.org/10.1128/AEM.66.9.37223726.2000

29. Cooney J, De Rome L, Laurence O, Gadd GM. Effects of organotin and organolead compounds on yeasts. J Indus Microbiol 1989;4:279-88. Available via https://link.springer.com/article/10.1007/BF01577351

30. Harino H, Fukushima M, Kurokawa Y, Kawai S Susceptibility of bacterial populations to organotin compounds and microbial degradation of organotin compounds in environmental water. Environ Pollut 1997;98:157-62; http://doi.org/10.1016/S02697491(97)00133-4

31. Cruz A, Caetano T, Suzuki S, Mendo S. Aeromonas veronii, a tributyltin (TBT)-degrading bacterium isolated from an estuarine environment, Ria de Aveiro in Portugal. Mar Environ Res 2007;64:639-50; http:// doi.org/10.1016/j.marenvres.2007.06.006

32. Jude F, Arpin C, Brachet-Castang C, Capdepuy M, Caumette P, Quentin C. TbtABM, a multidrug efflux pump associated with 
tributyltin resistance in Pseudomonas stutzeri. FEMS Microbiol Lett 2004;232(1):7-14; http://doi.org/10.1016/S0378-1097(04)00012-6

33. Wuertz S, Miller CE, Pfister RM, Cooney JJ Tributyltin-resistant bacteria from estuarine and freshwater sediments. Appl Environ Microbiol 1991;57:2783-9; http://doi.org/10.1128/aem.57.10.27832789.1991

34. White JS, Tobin JM, Cooney JJ. Organotin compounds and their interactions with microorganisms. Can J Microbiol 1999;45:541-54 http://doi.org/10.1139/w99-048

35. Suzuki S, Fukagawa $\mathrm{T}$ Tributyltin-resistant marine bacteria: a summary of recent work. J Indus Microbiol 1995;14(2):154-8; http:/ doi.org/10.1007/BF01569897

36. Monteiro HR, Moutinho AB, Campos MJ, Esteves AC, Lemos MF. Insights into the restoration of tributyltin contaminated environments using marine bacteria from Portuguese fishing ports. Appl Sci 2021;11(14):6411; http://doi.org/10.3390/app11146411

37. Abubakar A, Ibrahim S, Garba IK, Tanko AS, Abdulrasheed M, Adamu A, et al. Kinetics modelling of tributyltin toxicity on the growth of Bacillus stearothermophilus. Biorem Sci Technol Res 2020;8(1):7-10; Available via https://journal.hibiscuspublisher.com/ index.php/BSTR/article/view/509

38. Hassan HA, Dawah SE, El-Sheekh MM. Monitoring the degradation capability of novel haloalkaliphilic tributyltin chloride (TBTCl) resistant bacteria from butyltin-polluted site. Rev Argent Microbio 2019;51(1):39-46; http://doi.org/10.1016/j.ram.2017.12.002

How to cite this article:

Kumar BA, Triveni G, Gundluri BR, Berde CV, Pallaval VB. Isolation and identification of potent tributyltin chloride utilizing Pseudomonas sp. strain VBAK from Vishakhapatnam shipping harbor sediments. J Appl Biol Biotech 2022; 10(02):12-20. 